\title{
The Implications of Technical Language in Defining, Assessing, and Managing Risk
}

\author{
Hamilton Bean \\ Department of Communications \\ University of Colorado-Denver \\ Denver, CO USA \\ David A. Clanaugh \\ Department of Humanities \\ Michigan Technological University \\ Houghton, MI USA
}

Poroi 8,1 (April 2012)

The concept of risk is becoming an established focus of rhetorical scholars and critics. As was recently argued in the pages of this journal, "Research on the significance of affective forces in determining how people perceive risk ... creates ample opportunities for rhetorical studies to complement social scientific research on cognition of risk" (Schwartzman, Ross, and Berube, 2011, 1). Schwartzman et al. identified several issues that scholars might reflect on in developing a more "rhetoricized" approach to risk. These include: 1) the inaccessibility of science to lay audiences; 2) the role of uncertainty in gaining and maintaining public trust; 3 ) the influence of speculation and sensationalism in diminishing the impact of scientific research; 4) the problem of both too little and too much information in times of crisis; 5) skepticism about experts; 6) the role of narrative in risk perception; and 7) audience differences in risk-related activities. Related to most of these issues is the role of technical obfuscation within riskrelated controversies (Taylor et al., 2008).

Neil Smith argues for critical awareness of the social production of technical knowledge as it relies upon figurative language within a context of dynamic material conditions and social relationships (Smith, 1990). We see the need for critical rhetorical practice, for example, with regard to the shorthand phrases, acronyms, and metaphors that constantly emerge from discussions people have about the risks and benefits of technology-driven development. Who does not prefer - at their own risk - a pithy, common acronym over a tortuous litany of scientific and technical jargon? Yet, language use can and does powerfully reinforce the contemporary breakdown in calculating, insuring, and managing risk (Beck, 2009). Smith's notion of uneven geographical development prepares ground for theorizing risk communication with the figurative landscape of uneven rhetorical development. The tension between 
equalization and differentiation within late capitalism produces uneven geographical development, which has parallels in the discursive and rhetorical landscape. Depending on where people are located in the social formation, and their relative degrees of power, they communicate differently about risk, using different metaphors, figures of speech, and arrangements of rhetorical appeals. This situation is in tension with scientific discourse production as the latter seeks to produce objective, standardized discourse about risk even as it struggles with the influences of complexity, underdetermination, and overdetermination. What results is uneven discourse about risk that makes it more difficult to identify risks and then calculate, deliberate, and adjudicate those risks. Thus, variation in language use contributes to the production of nature as we debate and choose our actions within the world with regard to situations of risk.

\section{The Shifting Figurated Landscape of Technical Acronyms}

David Clanaugh's research considers how technical language enters, changes, and functions in mediated public conversations in ways that often oversimplify, confuse, and affect scientific, social, political, and economic dynamics and impacts. He has been examining how the acronym-laden discourse about numerous proposed metallic sulfide mines in the Upper Great Lakes Region increasingly reflects a rhetoric of manipulation and special interests instead of the rhetoric of shared inquiry and democratic decision-making that Waddell outlines (1995). The conversation has devolved to "pro" and "anti" interest groups attempting to paint mining as either completely good or completely bad. Mining opponents focus on Acid Mine Drainage (AMD) as pervasive, intractable, and as what comes of as an unqualified condemnation of mining. Advocates talk about Acid Rock Drainage (ARD) as something that already occurs naturally and has a dilute, gradual, minor impact; hence, mines and mining are not causes for concern. The corporateowned mainstream media favor ARD; environmentalists do not see how importing AMD from another geographic context (Appalachia) alienates the people (many of them iron miners or their relatives) whom they wish to engage through mainstream media representations or visits to organizational websites. Numerous letters to the editor and blog posts reflect this opposition of AMD and ARD as reinforcing polarization. An underlying irony is the debate about acronyms has, until relatively recently, muted discussions about democratic process and economic justice.

Absent has been an accurate yet nuanced sense of human, natural, and technological agency, as well as a recognition that boundaries among forms of agency are more permeable than mainstream cultural assumptions admit (Latour, 1993). At this point, it is worth noting this region has a sizable indigenous population with different metaphysical perspectives that further complicates the landscape of rhetoric and agency. Also absent has been an understanding of how the acronyms function and compete as what Latour calls figurations (2005, 53-54). These figurations abstract and hypostatize agency as "within" discrete objects instead of distributed "among" agents within evolving associations 
and networks. This can then elide the enactments of power and inequities within those networks. Another problem is that these shorthand terms leave unaddressed the temporal and spatial disjunctions involved with environmental impacts and risks that pose representational challenges in environmental discourses that often shortchange the interests of the socially disenfranchised (Nixon, 2011). The prevailing acronyms confirm existing assumptions and prejudices that foreclose more productive community conversations.

A critical analysis of the rhetorical and figurative dimensions of technical language in popular translation can open the way toward a more accurate and nuanced sense of agency, greater temporal and spatial understandings of environmental impacts, rhetorical accountability in the service of effective risk communication, a vital play of democratic process, and a egalitarian sense of informed consent to the choices being made within the community. Such analysis can help lead us toward visions of environmental democracy as proposed by Latour (2004) and Serres (1995).

\section{Technical Metaphors of Communication}

Hamilton Bean's research examines how technical language mediates the ways that audiences conceptualize risk, as well as how officials warn publics about imminent dangers. In 2006, President George W. Bush issued Executive Order 13407, "Public Alert and Warning System," which aimed to create an effective and reliable system to warn the American people in the event of war, terrorist attack, natural disaster, and other hazards. As a result, FEMA is currently deploying a national Integrated Public Alert and Warning System (IPAWS). FEMA and its public and private industry partners are hoping that IPAWS will "transform the national alert and warning system to enable rapid dissemination of authenticated alert information over as many communications pathways as possible" (FEMA, 2012). These pathways include traditional, mobile, and social media. However, the ways that stakeholders conceptualize communication necessarily influences the development and effectiveness of systems such as IPAWS and related efforts (Axley, 1984).

Importantly, a 2011 report from the National Consortium for the Study of Terrorism and Responses to Terrorism (START), co-authored by Bean, suggests that the practice of public warning is based largely upon a "conduit metaphor" of communication. An implication of this metaphor, says Axley (1984), is that when meanings can be transferred as though there was conduit between speaker and message recipient, "There is good reason for self-assurance. Everyone is clearly understood-or at least thinks so" (p. 432).

A rhetorical perspective challenges this assumption on multiple levels. Specifically, a rhetorical perspective acknowledges that miscommunication and unintended meanings are more widespread than IPAWS stakeholders would like to admit. This is because responses to messages are based on receiver (not sender) meanings. Rhetorical critics can thus problematize the unstated assumptions underwriting the use of technical language and associated metaphors in risk communication. 
Rhetorical critics can focus on the work that technical language performs in shaping public understanding of technologies-such as IPAWS. In focusing on this work, the rhetorical critic can examine stakeholders' use of narratives, metaphors, and specific rhetorical strategies and devices. In this way, rhetorical scholars and critics can contribute to developing public understanding of the implications of technical language in identifying, assessing and managing risk.

\section{References}

Axley, S. R. (1984). Managerial and organizational communication in terms of the conduit metaphor. The Academy of Management Review, 9, 428-437.

Beck, U. (2009) World at risk. C. Cronin (Trans.). Malden, MA: Polity.

FEMA. (2012). Integrated public alert and warning system (IPAWS). Available from http://www.fema.gov/emergency/ipaws/.

Latour, B. (1993). We have never been modern. C. Porter (Trans.). Cambridge, MA: Harvard UP.

(2004). Politics of nature: How to bring the sciences into democracy. C. Porter (Trans.). Cambridge, MA: Harvard UP.

(2005). Reassembling the social: An introduction to actornetwork-theory. New York, NY: Oxford UP.

National Consortium for the Study of Terrorism and Responses to Terrorism. (2011). Research review. Available from http://www.start.umd.edu/start/announcements/announcement.asp ?id $=260$

Nixon, R. (2011). Slow violence and the environmentalism of the poor. Cambridge, MA: Harvard UP.

Schwartzman, R; Ross, D. G., \& Berube, D. M. (2011). Rhetoric and risk. Poroi, 7. Available from http://ir.uiowa.edu/poroi/vol7/iss1/9.

Serres, M. (1995). The Natural Contract. E. MacArthur \& W. Paulson (Trans.) Ann Arbor, MI: U of Michigan P.

Smith, N. (2008). Uneven development: Nature, capital, and the production of space. (3rd. ed.). Athens, GA: U of Georgia P.

Taylor, B. C. et al. (Eds.). (2007). Nuclear legacies: communication, controversy, and the U.S. nuclear weapons complex. Lanham, MD: Lexington Books.

Waddell, C. (1995). Defining sustainable development: A case study in environmental communication. Technical Communication Quarterly, 4, 201-216. 